\title{
FAUNAL FEATURES OF CADDISFLIES (INSECTA, TRICHOPTERA) IN KONAVLE REGION (CROATIA) WITH NOTES ON DNA BARCODING AND CONSERVATION BIOLOGY
}

\author{
Mladen Kučinići ${ }^{\text {, Ana ŠAlinović-Steinbacher }}{ }^{2}$, SAnja Žalac ${ }^{3}$, \\ Danijela Gumhalter ${ }^{4}$, Dora Hlebec ${ }^{1}$, AnĐela Ćukušić ${ }^{5}$, IVan VučKović ${ }^{6}$, \\ Martina Ššsić ${ }^{7}$, Iva Mihoci ${ }^{7}$, Julijana Haijna ${ }^{8} \&$ Mladen Vajdić $^{7}$ \\ ${ }^{1}$ Department of Biology, Faculty of Science, University of Zagreb, Rooseveltov $\operatorname{trg} 6$, \\ 10000 Zagreb, Croatia \\ ${ }^{2}$ Postelska ulica 10, 2000 Maribor, Slovenia \\ ${ }^{3}$ ZSC "Dr. Ivo Pevalek", Plitvice Lakes National Park, Josipa Jovića 19, 53231 Plitvička jezera, Croatia \\ ${ }^{4}$ Azuritweg 2, 70619 Stuttgart, Germany \\ ${ }^{5}$ Ministry of Economy and Sustainable development, Radnička cesta 80/7, 10000 Zagreb, Croatia \\ ${ }^{6}$ Elektroprojekt d.d., Civil and Architectural Engineering Department, Alexandera von Humboldta 4, \\ 10000 Zagreb, Croatia \\ ${ }^{7}$ Croatian Natural History Museum, Demetrova 1, 10000 Zagreb, Croatia \\ ${ }^{8}$ Dom zdravlja Zagreb - zapad, Hrvoja Macanovića 2a, 10000 Zagreb, Croatia
}

Kučinić, M., Šalinović-Steinbacher, A., Žalac, S., Gumhalter, D., Hlebec, D., Ćukušić, A., Vučković, I., Šašić, M., Mihoci, I., Hađina, J. \& Vajdić, M.: Faunal features of caddisflies (Insecta, Trichoptera) in Konavle region (Croatia) with notes on DNA barcoding and conservation biology. Nat. Croat., Vol. 30, No. 2, 331-350, Zagreb, 2021.

Throughout this research, 230 Trichoptera specimens were collected in the area of Konavle region, the southernmost area of Croatia. Altogether 21 species, 15 genera and 11 families were identified. DNA barcoding covered 41 specimens represented with 15 species collected in the Konavle region. The highest number of species was recorded at two localities: the spring of the River Ljuta (13) and a spring in the village Vodovađa (8). The highest number of taxa (4) was recorded within the following two families: Hydroptilidae and Hydropsychidae. From a faunistic point of view, the most interesting species in Konavle region are: Agapetus cf. kampos Oláh (the first record for Croatia), Hydroptila martini Marshall (the first record for the Mediterranean part of Croatia), Oxyethira falcata Morton (the first record for Croatia), Tinodes andrasi Oláh (type locality of the species is River Ljuta), Diplectrona cf. atra McLachlan (the first record from the Mediterranean part of Croatia) and Micropterna wageneri Malicky (the second record for Croatia). The first DNA barcoding data for the species Agapetus cf. kampos Oláh and Tinodes andrasi Oláh were entered into the BOLD database. The area of Konavle represents one of the most interesting regions for the fauna of Trichoptera and can be considered as a "hotspot" for caddisflies in Croatia. Thus, it is necessary to install high standards for their protection.

Keywords: fauna, aquatic insects, the River Ljuta, south Croatia, mitochondrial DNA

Kučinić, M., Šalinović-Steinbacher, A., Žalac, S., Gumhalter, D., Hlebec, D., Ćukušić, A., Vučković, I., Šašić, M., Mihoci, I., Hađina, J. \& Vajdić, M.: Faunističke značajke tulara (Insecta, Trichoptera) Konavala (Hrvatska) sa zabilješkama o DNA barkodiranju i konzervacijskoj biologiji. Nat. Croat., Vol. 30, No. 2, 331-350, Zagreb, 2021.

U sklopu ovoga istraživanja na području Konavala, najjužnijeg područja u Hrvatskoj, prikupljeno je 230 primjeraka tulara. Utvrđena je prisutnost 21 vrste, 15 rodova i 11 porodica. DNA barkodiranje 
provedeno je na 41 primjerku, odnosno na 15 vrsta prikupljenih na području Konavala. Najveći broj vrsta prikupljen je na dva lokaliteta: izvor rijeke Ljute (13) i izvor u selu Vodovađa (8). Najveći broj svojti (4) bio je zabilježen unutar sljedeće dvije porodice: Hydroptilidae i Hydropsychidae. S faunističkog gledišta najzanimljivije vrste zabilježene u Konavlima su: Agapetus cf. kampos Oláh (prvi nalaz za Hrvatsku), Hydroptila martini Marshall (prvi nalaz za mediteranski dio Hrvatske), Oxyethira falcata Morton (prvi nalaz za Hrvatsku), Tinodes andrasi Oláh (tipski lokalitet vrste je rijeka Ljuta), Diplectrona cf. atra McLachlan (prvi nalaz za mediteranski dio Hrvatske) i Micropterna wageneri Malicky (drugi nalaz za Hrvatsku). Prvi DNA barkodovi za vrste Agapetus cf. kampos Oláh i Tinodes andrasi Oláh uneseni su u BOLD bazu. Područje Konavala predstavlja jednu od najzanimljivijih regija za faunu Trichoptera i može se smatrati hotspot-om za tulare u Hrvatskoj. Iz tog je razloga potrebno uvođenje visokih standarda za njihovu zaštitu.

Ključne riječi: fauna, vodeni kukci, rijeka Ljuta, južna Hrvatska, mitohondrijska DNA

\section{INTRODUCTION}

Studies on caddisflies in Dalmatia, the southernmost region of Croatia, started at the beginning of the $19^{\text {th }}$ century when the famous entomologist and mineralogist, Professor of Zoology and Director of the Mineralogical Museum in Halle, Prof. Ernst F. Germar, Ph.D., started collecting insects in 1811 while visiting Dalmatia. According to Nonveiller (1989), Germar included Phryganea atrata Fabricius (Germar, 1817) in his species list for this region. Phryganea atrata Fabricius is a synonym of Notidobia ciliaris Linnaeus (Morse, 2021), and it was probably the first caddisfly species recorded in the fauna of Croatia. Throughout later investigations on Trichoptera fauna, different areas of Dalmatia were covered, for example, the rivers Krka, Neretva, Cetina Zrmanja, Ruda, Grab and Rumin, Mt Biokovo, and the islands of Pag and Hvar. As a result of these investigations, the faunal features of Trichoptera from this region are well known (e.g. Graf et al., 2008a; KaraOuZas et al., 2015; Kučinić \& Ilić 1993; Kučinić et al., 2011, 2019a, 2019b, 2020a, 2020b; Malicky, 1979, 1980, 2005, 2014; Oláh 2010; Previšić et al., 2014; VučKović et al., 2011, 2021; WARInger et al., 2009). Additionally, three new-to-science Trichoptera species were discovered: Athripsodes dalmatinus Malicky, Tinodes andrasi Oláh, and Ecclisopteryx ivkae Previšić, Vitecek \& Graf (MALICKY, 1980; Oláh, 2010; Previšić et al., 2014); three species as yet undescribed in larval stage were also described: Tinodes braueri McLachlan, Ecclisopteryx ivkae Previšić, Vitecek \& Graf and Annitella apfelbecki Klapálek (GrAf et al., 2008a; Previšić et al., 2014; WARINGER et al., 2009), and one undescribed female caddisfly: Annitella apfelbecki (VučKović et al., 2011).

The southernmost area of Dalmatia, as well as the southernmost county of Croatia, is Konavosko polje (plain) or Konavle (Fig. 1) (BERTić et al., 2001; http:/ / www.enciklopedija.hr, ŠALINOVIĆ 2019). The narrow plain of Konavle is an isolated valley in south Croatia, located between Bosnia and Herzegovina in the north, Montenegro in the east, and the Croatian part of the Adriatic Sea in the south-east.

Caddisfly research in Konavle started in 2000 and has continued more or less until today. During this research period one new species, Tinodes andrasi Oláh was described by Hungarian researchers (OLÁH, 2010). To date, four new Trichoptera species have been recorded for the area of Konavosko polje: Rhyacophila tristis Pictet, Tinodes andrasi, Oláh, Silo nigricornis Pictet and Micropterna wageneri Malicky (KučInIĆ et al., 2017a, 2020b; OLÁH, 2010). 
This article aims to give information on biodiversity, distribution and seasonal dynamics of Trichoptera species collected throughout field investigations conducted in Konavle during the last 20 years; (1) features of the DNA barcoded caddisfly specimens from this region, which have been a research topic in recent years (2), the protection of the aquatic insect fauna, including caddisflies, of Konavle area (3).

\section{MATERIAL AND METHODS}

\section{Study area and field work}

Konavle (Konavosko polje, plain) is the southernmost part of Croatia (Fig. 1). It is $22 \mathrm{~km}$ long, $6 \mathrm{~km}$ wide, and has a surface area of approximately $75 \mathrm{~km}^{2}$. It is a valley enclosed on the northern and eastern side by mountains (these mountains being also part of the Konavle region), the southern side has its border on the Adriatic sea and the western side on the line between the town of Cavtat and Župa Dubrovačka (BERTić et al., 2001; ŠS Alinović, 2019). The area extends northwest to southeast. Considering the pedological characteristics, Konavle is an area of carbonate bedrock, which represents an impermeable medium. From a hydrogeological point of view, Konavle is not an area rich in running fresh surface watercourses. Highlight is the River Ljuta which, after flowing only a few kilometers through Konavosko polje, flows into the Adriatic Sea. Besides the Ljuta - the most dominant aquatic habitat in Konavle - there are several smaller streams, springs, canals, the small river Konavočica, which dries out in the summertime, and a few anthropogenic ponds.

The area of Konavle was visited eight times from 2000 until 2020 for a total of 21 field days. The Trichoptera species were collected at altogether eight different locali-

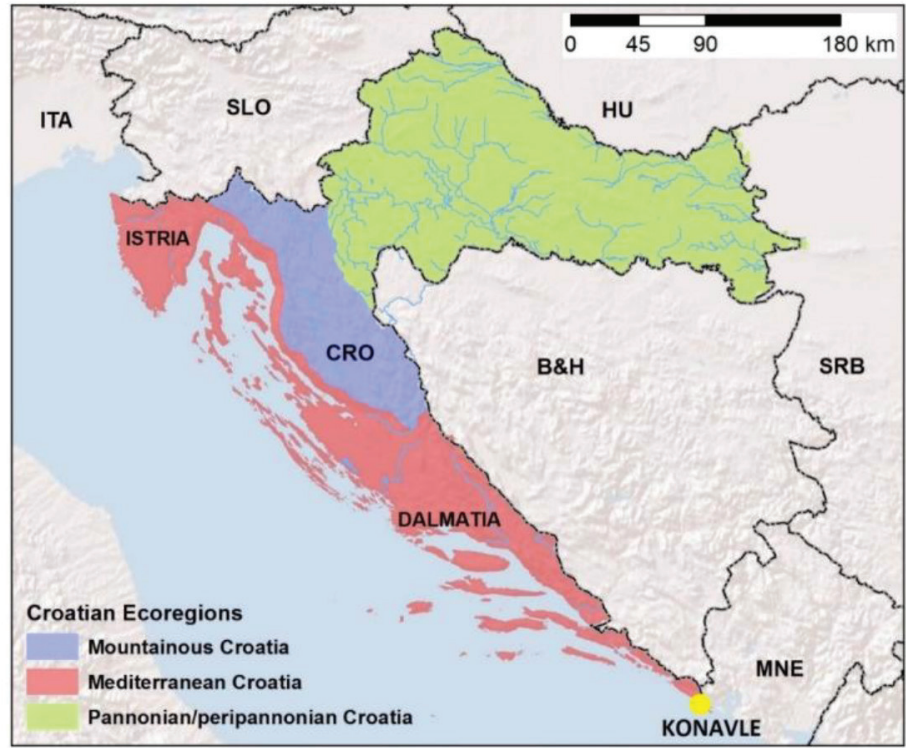

Fig. 1. Three biogeographical regions in Croatia, according to BerTić et al. (2001): Pannonian-peripannonian Croatia - continental area (green), Mountainous Croatia - central mountain area (blue) and Mediterranean Croatia (pink), with the Konavle region (marked with yellow circle). 
ties: spring of the River Ljuta (1), the River Ljuta, upper part (2), the River Ljuta, middle part (3), spring in the village of Vodovađa (4), spring next to the Villa Marija (second spring in the village of Vodovađa) (5), stream in the village of Palje Brdo (6), stream in the village of Lovorno (7), and stream in the village of Pridvorje (8).

For each locality a short preview of the main hydrological features is given:

1. Spring of the River Ljuta (Fig. 2A) consists of several separate springs, which together form one of the strongest spring areas in the Mediterranean part of Croatia. The River Ljuta is the only liquid surface fresh water in Konavle with a whole spectrum of microhabitats that feature a bottom of huge to small rocks, gravel, sand, and habitats that are covered with moss. The spring of the River Ljuta is a typical strong karst rheocrene spring. It is located 100 meters above sea level within forest vegetation, which is dominated by laurel and holm oak. The spring never dries up.

2. The River Ljuta, upper part (Fig. 2B-C). The locality is located 150 meters downstream from the spring of the River Ljuta. This is the place where the river divides into the main stream and several side streams (brooks), near the restaurant Konavoski dvori. The benthos covers a wide spectrum of microhabitats like pebble, gravel, or moss. The locality is situated within very well developed forest vegetation, which is dominated mainly by holm oak and less by laurel. It is located 61 meters above sea level.

3. The River Ljuta, middle part (Fig. 2D) is located about 400 meters away from the spring of the River Ljuta. At this point, the river flows is much slower and the river bed is some seven to eight meters wide. The bottom consists of pebble, gravel, and some moss-covered areas. The locality is located at 57 meters above sea level on the left side of the tarmac road leading to the village of Grude, and it is not located within forest vegetation.

4. The karst rheocrene spring in the village of Vodovađa (Fig. 2E) is partially artificial and partially emerges from a cave. It has less power but never dries up. On the bottom part and the upper part, which has a width of $70 \mathrm{~cm}$ and a length of about 14 $\mathrm{m}$, pebble, moss, and gravel dominate. The rest of the upper part of the stream is canalized on a hillslope and is very fast-flowing. This is the easternmost research locality in the area of Konavosko plain and one of the easternmost springs in Croatia. It is located on the eastern slopes of Mt Snježnica at an altitude of 305 meters above sea level, without forest vegetation.

5. The spring of Marija (Fig. 2F), close to the Villa Marija in the village of Vodovađa is a smaller spring that is partially covered with stones. It belongs to small karst rheocrene springs and it never dries up. There are small pebbles covered with moss, gravel, and at some places sand on the bottom. The spring is located outside of the forest vegetation in an open area at an altitude of 227 meters above sea level.

6. The stream in the village of Palje Brdo is a locality on a bridge just outside the village of Palje Brdo. The brook is fast-flowing and partially on a hillslope. The locality is covered by Mediterranean scrub vegetation. There are small pebbles and gravel at the bottom. The locality is located at an altitude of 149 meters above sea level.

7. The stream in the village of Lovorno (Fig. 2G-H) is a smaller watercourse with a width of about 1 meter and a depth of 20 to 30 centimeters. At the bottom, there is sand, small and mid-sized pebbles. The locality is on an open area outside of the forest vegetation at an altitude of 85 meters above sea level. 

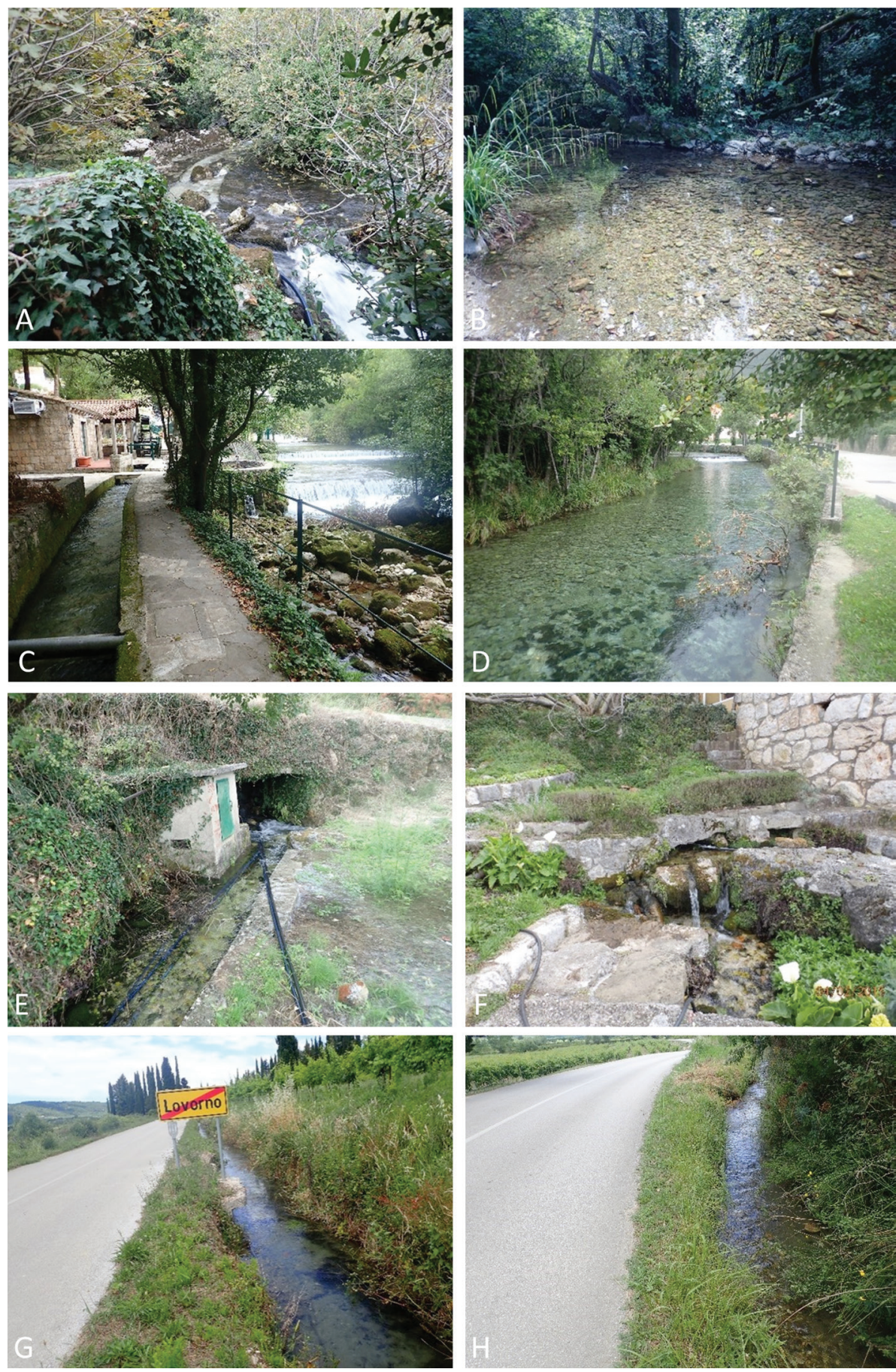

Fig. 2 A-H. Spring of the River Ljuta (A), the River Ljuta, upper part (B-C), the River Ljuta, middle part (D), the spring in the village of Vodovađa (E), the spring of Marija (village of Vodovađa) $(\mathrm{F})$, the stream in the village of Lovorno $(\mathrm{G}-\mathrm{H})$. 
8. The stream in the village of Pridvorje is a smaller watercourse similar to the brook in the village of Pridvorje. It is not a fast-flowing brook. The width is about 1.5 meters and the bottom is covered by pebbles, gravel, and sand. The locality is also located on an open area outside the forest vegetation at an altitude of 61 meters above sea level.

The collecting of Trichoptera was done at all localities with portable $12 \mathrm{~V} \mathrm{UV}$ lamps. The collection period was one hour at each locality. As well as at night, the caddisflies were also collected during daytime from the surrounding vegetation with an entomological net. The collected material was preserved in $80 \%$ or absolute alcohol for morphological and molecular analysis, respectively.

The collected specimens are all part of four collections: the NIP Trichoptera collection deposited in the Croatian Natural History Museum in Zagreb, the Trichoptera collection of the Faculty of Science at the University of Zagreb, "Pogledi Nova Trichoptera DNA barcoding collection" deposited in the Croatian Natural History Museum in Zagreb", and the first author's research collection.

\section{DNA extraction and gene amplification}

Genomic DNA was extracted from a single leg of each specimen using GenElute Mammalian Genomic DNA Miniprep kit (Sigma-Aldrich, Germany) following the manufacturer's protocol and eluted in $50 \mu \mathrm{L}$ of elution buffer. The standard DNA barcode region of mitochondrial cytochrome oxidase subunit I gene (COI) was amplified using standard PCR-protocols and two primer sets LCO-1490/HCO-2198 (FoLMer et al., 1994) and C_LepFolF/C_LepFolR (Hebert et al., 2004) in $20 \mu \mathrm{L}$ reaction mixture. Polymerase chain reactions (PCRs) were carried out using: 1 x DreamTaq ${ }^{\mathrm{TM}}$ reaction buffer with $2 \mathrm{mM} \mathrm{MgCl}$ (Thermo Fisher Scientific Inc., US), $0.2 \mathrm{mM}$ dNTPs (Qiagen), $0.4 \mu \mathrm{M}$ of each primer, $0.025 \mathrm{U} / \mu \mathrm{L}$ of DreamTaq polymerase (Thermo Fisher Scientific Inc., US) and $1 \mu \mathrm{l}$ of eluted DNA. The PCR cycling protocol included: initial denaturation at $95^{\circ} \mathrm{C}$ for $2 \mathrm{~min}$, followed by 35 cycles of denaturation at $95^{\circ} \mathrm{C}$ for $30 \mathrm{~s}$, annealing at $50{ }^{\circ} \mathrm{C}$ for $30 \mathrm{~s}$, extension at $72{ }^{\circ} \mathrm{C}$ for $1 \mathrm{~min}$, followed by a final extension step at $72{ }^{\circ} \mathrm{C}$ for $10 \mathrm{~min}$. Purification and sequencing were performed by Macrogen Inc. (Amsterdam, Netherlands) using the same amplification primers. Sequences obtained in this study were deposited in the Barcode of Life Database (Ratnasingham \& Hebert, 2007) (Tab. 4).

\section{Sequence data}

Sequences were checked, edited, and inspected manually for base pair ambiguities and stop codons in the program BioEdit v.7.2.5. (HALL, 1999). BOLD Identification Engine (accessed 14/06/2021) was used for comparison of obtained DNA sequences with sequences available in BOLD database.

\section{Systematic presentation}

Determination of all species was done according to Kumanski $(1985,1988)$ and Malicky (2004). An exception was the determination of Tinodes andrasi and Agapetus cf. kampos which was done according to OláH (2010) and OláH \& Kovács (2013). Systematics followed Morse (2021). On the basis of our research, a degree thesis was prepared (Š́ALINOVIĆ, 2019), the results of which were partially corrected in this paper. 


\section{RESULTS}

Throughout this research, 230 caddisflies specimens were collected in the plain of Konavle. Altogether 21 species, 15 genera and 11 families were identified (Tabs 1-2). The highest number of taxa (4) was recorded within the families Hydroptilidae, and Hydropsychidae (Tab. 1). Seven families were represented only by one species (Tab. 1). The most numerous genera, represented by three species per genus, are Hydroptila Dalman, Tinodes Curtis and Hydropsyche Pictet. Altogether 12 out of 15 genera are represented only by one species per genus (Tab. 2).

The highest number of species was recorded on the localities: spring of the River Ljuta (13 species) and spring in the village of Vodovađa (8 species) (Tab. 2). The presence of only 3 species was confirmed at 2 localities: the spring of Marija and the stream in the village of Lovorno (Tab. 2).

From a faunistic point of view, the most interesting species in the Konavle region are: Agapetus cf. kampos Oláh (the first record for Croatia, the second record for this species after the type locality), Hydroptila martini Marshall (the first record for the Mediterranean part of Croatia), Oxyethira falcata Morton (the first record for Croatia), Tinodes andrasi Oláh (type locality of the species is River Ljuta), Diplectrona cf. atra McLachlan (the first record in the Mediterranean part of Croatia), and Micropterna wageneri Malicky (the second record for Croatia).

The highest number of recorded species, 10, was collected in June, August and October, and only two species were recorded in May and three in April and November (Tab. 3). During the winter months, no specimens were collected. Three species have the longest flying period in the area of Konavle. Hydropsyche instabilis Curtis was recorded during six and Agapetus cf. kampos Oláh and Diplectrona cf. atra McLachlan during five months (Tab. 3).

DNA barcoding covered 15 species represented by 41 specimens collected in the Konavle region (Tab. 4). The first DNA barcoding data for the species Agapetus cf. kampos Oláh and Tinodes andrasi Oláh were entered into the BOLD database. The results of this research indicate interesting genetic characteristics from the populations of Agapetus cf. kampos Oláh, Tinodes andrasi Oláh and Diplectrona cf. atra McLachlan. The results of DNA barcoding also enable a more precise identification of the species from the family Hydroptilidae (Tab. 4).

Systematic presentation of caddisflies collected in the Konavle region with data of collection dates and number of collected females and males follows.

\section{Family Rhyacophilidae}

Rhyacophila tristis Pictet, 1834

spring of the River Ljuta, 20.06.2020, 1 q, spring in the village of Vodovađa, 31.10.2015, 2 ठึ

\section{Family Glossosomatidae}

Agapetus cf. kampos (Fig. 3 A-C)

spring of the River Ljuta, 24.09.2004, 2 qq$, 13 \hat{\jmath} \widehat{\jmath}, 3.07 .20071 \hat{\jmath}, 17.08 .2016,1 q, 2$

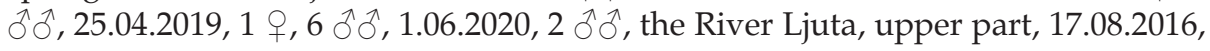
1 ㅇ 


\section{Family Hydroptilidae}

Hydroptila martini Marshall, 1977

stream in the village of Pridvorje, 17.08.2016, 1 ह

Hydroptila sparsa Curtis, 1834

stream in the village of Pridvorje, 17.08.2016, 1 ๙

Hydroptila vectis Curtis, 1834

stream in the village of Pridvorje, 17.08.2016, $1 \hat{\jmath}$

Oxyethira falcata Morton, 1893

stream in the village of Pridvorje, 17.08.2016, 3 ○ろ

Hydroptilidae sp. (female)

stream in the village of Pridvorje, 17.08.2016, 10 우

\section{Family Polycentropodidae}

Polycentropus excisus Klapálek, 1894

spring of the River Ljuta, 24.09.2004, 2 ふึત

\section{Family Psychomyiidae}

Tinodes andrasi Oláh, 2010 (Fig. 4)

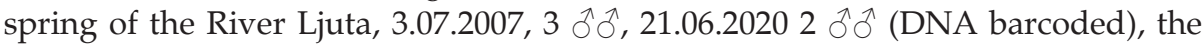
River Ljuta, upper part, 5.10.2020, 10
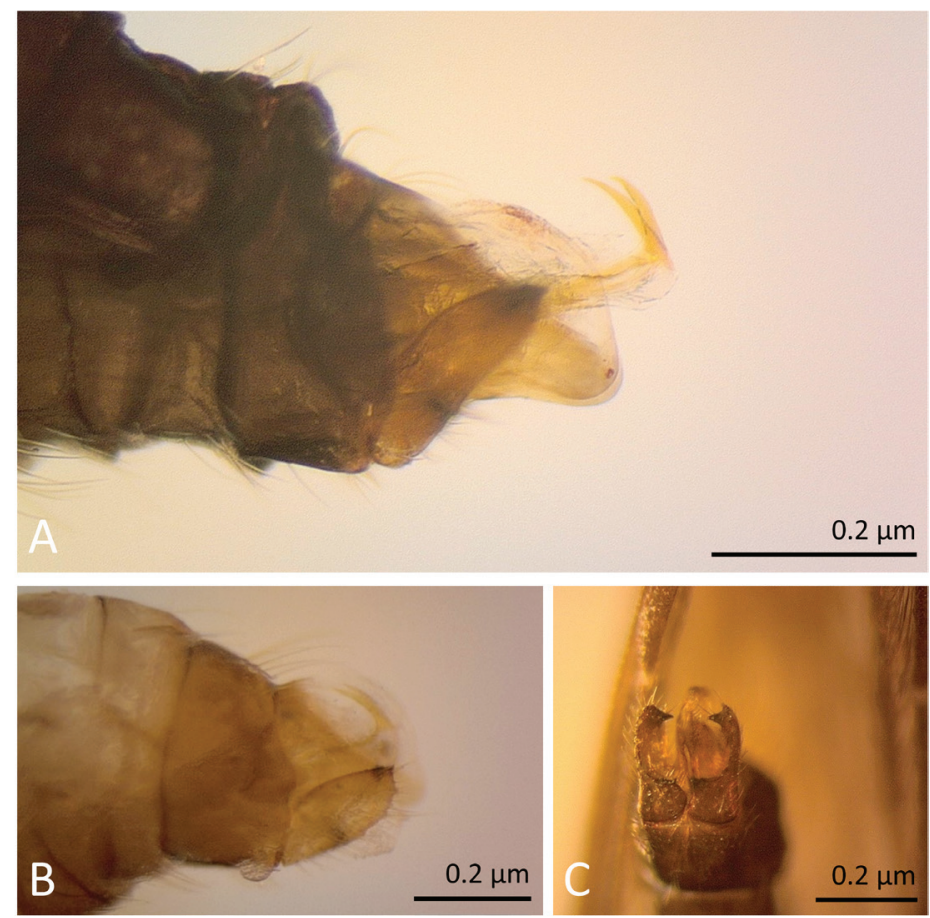

Fig. 3 A-C. Agapetus cf. kampos Oláh, male imago, lateral view, left side (A-C), ventral side (C) (imago collected in the spring of the River Ljuta, 3.07.2007) (photo Ana Mrnjavčić Vojvoda). 


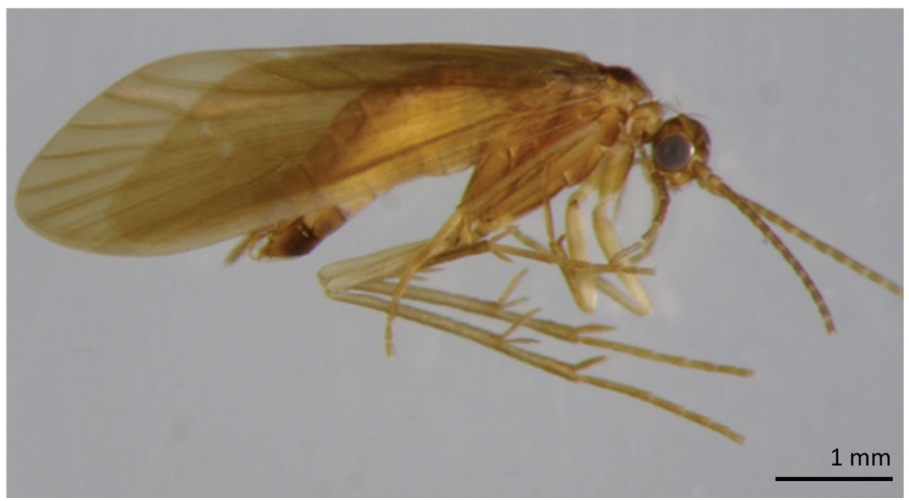

Fig. 4. Tinodes andrasi Oláh, male imago, lateral view, right side (imago collected in the spring of the River Ljuta, 3.07.2007) (photo Ana Mrnjavčić Vojvoda).

Tinodes braueri McLachlan, 1878

spring of the River Ljuta, 1.11.2015, $2 \hat{\delta} \hat{\sigma}, 4.10 .2020,1 \hat{\sigma}, 21.06 .2020$, the River Ljuta, upper part, 12.10.2008, $5 \hat{\partial} \widehat{\jmath}, 20.06 .2020,1 \hat{\jmath}$, the River Ljuta, middle part, 31.10.2015, 1 ठै

Tinodes pallidulus McLachlan, 1878

spring of the River Ljuta, 20.06.2020, $1 \hat{\jmath}$

Tinodes sp.

spring of the River Ljuta, 24.09.2004, 1 q, 28.06.2007, 1 q , 4.10.2020, 2 q $q$, the River Ljuta, upper part, 12.10.2008, 1 \%, the River Ljuta, middle part, 2.04.2015, 1 , 4.10.2020, 2 우

\section{Family Hydropsychidae}

Diplectrona cf. atra McLachlan, 1878 (Fig. 5 A-B)

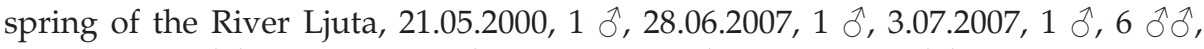

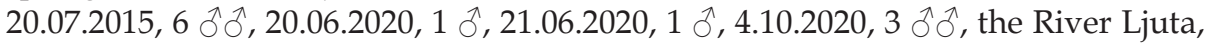
upper part, 12.10.2008, $1 \hat{\delta}, 20.06 .2020,3 \hat{\jmath} \hat{\jmath}$, the River Ljuta, middle part, 1.04.2015, $1 \hat{\sigma}$, spring in the village, Vodovađa, 21.07.2015, $3 \hat{\partial}$

Hydropsyche angustipennis Curtis, 1834

stream in the village of Lovorno, 17.08.2016, 10

Hydropsyche fulvipes Curtis, 1834

stream in the village of Palje Brdo, 21.07.2015, 1 え

Hydropsyche instabilis (Curtis, 1834)

spring of the River Ljuta, 24.09.2004, $1 \hat{\jmath}, 28.06 .2007 ., 2 \hat{\jmath}, 20.07 .2015,1 \hat{\jmath}$,

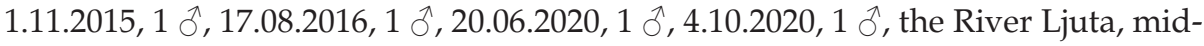
dle part, 1.11.2015, $3 \hat{\jmath}$, spring in the village of Vodovađa, 21.07.2015, $1 \hat{\jmath}$, stream in the village of Palje Brdo, 21.07.2015, $6 \hat{\partial} \bar{\partial}$, stream in the village of Lovorno,

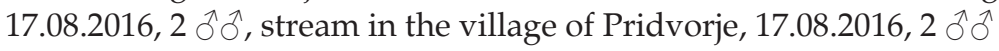



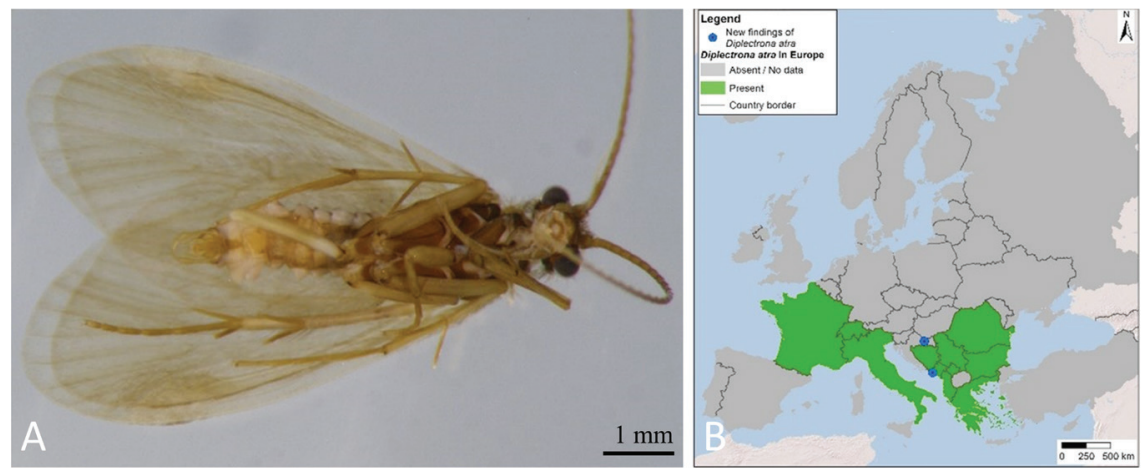

Fig. 5 A-B. Adults of Diplectrona cf. atra McLachlan, ventral view (A) (imago collected it the spring of the River Ljuta, 3.07.2007) with distribution according to Fauna Europea (B).

Diplectrona sp. \& Hydropsyche sp.

spring of the River Ljuta, 24.09.2004, 1 , , 24.09.2004, 8 qq , 28.06.2007, 1 , 20.07.2015, 4 우, 20.07.2015, 6 우, 1.11.2015, 2 우, 17.08.2016 1 q , 20.06.2020, 1 의, the River Ljuta, upper part, 20.06.2020, 4 우, the River Ljuta, middle part, 1.11.2015, 1 , spring in the village, Vodovađa, 21.07.2015, 1 , , 16.08.2016, 4 우, stream in the village of Palje Brdo, 21.07.2015, $4+q$, stream in village of Lovorno, 4.10.2020., 1 , stream in the village of Pridvorje, 17.08.2016, 2 + + ,

\section{Family Goeridae}

Silo nigricornis (Pictet, 1834)

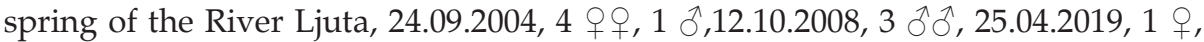

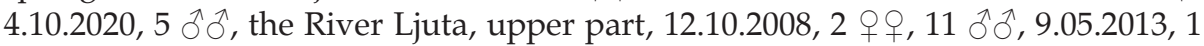

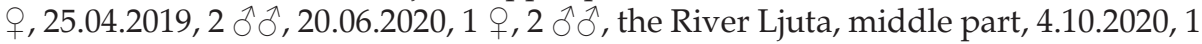
ㅇ, spring in the village of Vodovađa, 25.04.2019, $1 \hat{\sigma}$, the spring of Marija (village of Vodovađa), 5.10.2020, $1 \hat{\delta}$, stream in the village of Lovorno, 4.10.2020, 3 우, $1 \hat{\delta}$

\section{Family Limnephilidae}

Limnephilus lunatus Curtis, 1834

spring of the River Ljuta, 1.11.2015, 1 $+1 \stackrel{\curvearrowright}{\AA}$, spring in the village of Vodovađa, 31.10.2015, 1 ठ

Halesus digitatus (Rambur, 1842)

the River Ljuta, middle part, 31.10.2015, 1 o

Micropterna wageneri Malicky, 1971

spring of the River Ljuta, 1.11.2015, $1 \stackrel{+}{1} 1 \hat{\sigma}$, spring in the village of Vodovađa, 31.10.2015, 1 q $, 4.10 .2020,1$ q, 1 o , stream in the village of Palje Brdo, 31.10.2015, 10

\section{Family Sericostomatidae}

Sericostoma flavicorne Schneider, 1845

spring of the River Ljuta, 28.06.2007, 1 \& , 21.06.2020, 1 \&, spring in the village of Vodovađa, 16.08.2016, 1 ㅇ, 20.06.2020, 1 ㅇ 
Tab. 1. The number of families and species recorded from the area of Konavle.

\begin{tabular}{|c|c|c|c|}
\hline Families & Number of species & Families & Number of species \\
\hline Rhyacophilidae & 1 & Goeridae & 1 \\
\hline Glossosomatidae & 1 & Limnephilidae & 3 \\
\hline Hydroptilidae & 4 & Sericostomatidae & 1 \\
\hline Polycentropodidae & 1 & Odontoceridae & 1 \\
\hline Psychomyiidae & 3 & Leptoceridae & 1 \\
\hline Hydropsychidae & 4 & & \\
\hline
\end{tabular}

\section{Family Odontoceridae}

\section{Odontocerum albicorne (Scopoli, 1763)}

the River Ljuta, upper part, 20.06.2020, 1 ㅇ, 5.10.2020, $1 \hat{\delta}$, spring in the village of Vodovađa, 20.06.2020, 1 , the spring of Marija (the village of Vodovađa), 16.08.2016, 1 ठ

\section{Family Leptoceridae}

Adicella filicornis (Pictet, 1834)

spring of the River Ljuta, 21.05.2000, 1 q, 21.06.2020, $2 \hat{\jmath} \bar{d}$, the spring of Marija (the village of Vodovađa), 20.06.2020, $1 \sigma^{\pi}$

\section{DISCUSSION}

Previous research recorded four species of Trichoptera in the Konavle region: Rhyacophila tristis Pictet, Tinodes andrasi Oláh, Silo nigricornis Pictet and Micropterna wageneri Malicky (Kučinić et al., 2017a, 2020b; OLÁH, 2010). With the results of this research, these four species have been reconfirmed and 17 further previously unrecorded species were reported (Tab. 2). The number of 21 recorded species represents $10 \%$ of the Croatian Trichoptera fauna, which counts approximately to 210 species in total (Kučinić unpublished data).

The species number recorded in the Konavle region is not large if compared with the number of Trichoptera species recorded in other areas of Croatia. For example, 89 caddisfly species were recorded from Plitvice Lakes National Park (KučInić et al., 2017b), 77 species in the area of the River Dobra, River Kamačnik and Lake Sabljaci (Cerjanec, 2020), 77 species in the area of the River Cetina and its affluents (Graf et al., 2008a; MaLicky 2014; VuČKović, 2011; VučKović et al., 2021; WARINGER et al., 2009) or 56 species of the River Krka and its affluents (KučInIĆ et al., 2011, 2019a; RidL et al., 2017). Nonetheless, the peculiarity of the Konavle region is represented by its interesting composition of Trichoptera fauna (Tabs 2-4).

In the Konavle region a smaller number of species is conditioned primarily by the hydrological features, because the only liquid surface freshwater that does not dry up in this area is the River Ljuta with some smaller brooks. Other watercourses, like the river Konavočica, dry out. This surely impacts the structure and composition of the fauna on these habitats.

The results of this research include surveys from eight localities (Tab. 2). In the future, the number of localities will increase, and it can be expected that the number 
Tab. 2. Distribution of caddisflies at the research localities in the area of Konavle: 1 - spring of the River Ljuta, 2 -the River Ljuta, upper part, 3 - the River Ljuta, middle part, 4 - spring in the village of Vodovađa, 5 - the spring of Marija, 6 - stream in the village of Palje Brdo, 7 - stream in the village of Lovorno, 8 - stream in the village of Pridvorje, with literature data: Olá́ (2010) and Kučinić et al. (2017a, 2020b).

\begin{tabular}{|c|c|c|c|c|c|c|c|c|}
\hline \multirow{2}{*}{ Systematics } & \multicolumn{8}{|c|}{ L O C A L I T I ES } \\
\hline & 1 & 2 & 3 & 4 & 5 & 6 & 7 & 8 \\
\hline Family Rhyacophilidae & & & & & & & & \\
\hline Rhyacophila tristis Pictet & $\bullet$ & & & $\bullet$ & & & & \\
\hline Family Glossosomatidae & & & & & & & & \\
\hline Agapetus cf. kampos Oláh & $\bullet$ & $\bullet$ & & & & & & \\
\hline Family Hydroptilidae & & & & & & & & \\
\hline Hydroptila martini Marshall & & & & & & & & $\bullet$ \\
\hline Hydroptila sparsa Curtis & & & & & & & & $\bullet$ \\
\hline Hydroptila vectis Curtis & & & & & & & & $\bullet$ \\
\hline Oxyethira falcata Morton & & & & & & & & $\bullet$ \\
\hline Family Polycentropodidae & & & & & & & & \\
\hline Polycentropus excisus Klapálek & $\bullet$ & & & & & & & \\
\hline Family Psychomyiidae & & & & & & & & \\
\hline Tinodes andrasi Oláh & $\bullet$ & $\bullet$ & & & & & & \\
\hline Tinodes braueri McLachlan & $\bullet$ & $\bullet$ & $\bullet$ & & & & & \\
\hline Tinodes pallidulus McLachlan & $\bullet$ & & & & & & & \\
\hline Family Hydropsychidae & & & & & & & & \\
\hline Diplectrona cf. atra McLachlan & $\bullet$ & $\bullet$ & $\bullet$ & $\bullet$ & & $\bullet$ & & \\
\hline Hydropsyche angustipennis Curtis & & & & & & & $\bullet$ & \\
\hline Hydropsyche fulvipes Curtis & & & & & & $\bullet$ & & \\
\hline Hydropsyche instabilis Curtis & $\bullet$ & & $\bullet$ & $\bullet$ & & $\bullet$ & $\bullet$ & $\bullet$ \\
\hline Family Goeridae & & & & & & & & \\
\hline Silo nigricornis Pictet & $\bullet$ & $\bullet$ & $\bullet$ & $\bullet$ & $\bullet$ & & $\bullet$ & \\
\hline Family Limnephilidae & & & & & & & & \\
\hline Limnephilus lunatus Curtis & $\bullet$ & & & $\bullet$ & & $\bullet$ & & \\
\hline Halesus digitatus Rambur & & & $\bullet$ & & & & & \\
\hline Micropterna wageneri Malicky & $\bullet$ & & & $\bullet$ & & $\bullet$ & & \\
\hline Family Sericostomatidae & & & & & & & & \\
\hline Sericostoma flavicorne Schneider & $\bullet$ & & & $\bullet$ & & & & \\
\hline Family Odontoceridae & & & & & & & & \\
\hline Odontocerum albicorne Scopoli & & $\bullet$ & & $\bullet$ & - & & & \\
\hline Family Leptoceridae & & & & & & & & \\
\hline Adicella filicornis Pictet & $\bullet$ & & & & $\bullet$ & & & \\
\hline TOTAL NUMBER OF TAXA & 13 & 6 & 5 & 8 & 3 & 5 & 3 & 5 \\
\hline
\end{tabular}


Tab. 3. Seasonal dynamics of caddisflies in the area of Konavle (1-12 months), with literature data: OLÁH (2010) and KuČINIĆ et al. (2017a, 2020b).

\begin{tabular}{|c|c|c|c|c|c|c|c|c|c|c|c|c|}
\hline \multirow{2}{*}{ Systematics } & \multicolumn{12}{|c|}{ MONTHS } \\
\hline & 1 & 2 & 3 & 4 & 5 & 6 & 7 & 8 & 9 & 10 & 11 & 12 \\
\hline Family Rhyacophilidae & & & & & & & & & & & & \\
\hline Rhyacophila tristis Pictet & & & & & & $\bullet$ & & & & $\bullet$ & & \\
\hline Family Glossosomatidae & & & & & & & & & & & & \\
\hline Agapetus cf. kampos Oláh & & & & - & & - & - & - & - & & & \\
\hline Family Hydroptilidae & & & & & & & & & & & & \\
\hline Hydroptila martini Marshall & & & & & & & & $\bullet$ & & & & \\
\hline Hydroptila sparsa Curtis & & & & & & & & $\bullet$ & & & & \\
\hline Hydroptila vectis Curtis & & & & & & & & $\bullet$ & & & & \\
\hline Oxyethira falcata Morton & & & & & & & & $\bullet$ & & & & \\
\hline Family Polycentropodidae & & & & & & & & & & & & \\
\hline Polycentropus excisus Klapálek & & & & & & & & & - & & & \\
\hline Family Psychomyiidae & & & & & & & & & & & & \\
\hline Tinodes andrasi Oláh & & & & & & & $\bullet$ & & & $\bullet$ & & \\
\hline Tinodes braueri McLachlan & & & & & & $\bullet$ & & & $\bullet$ & $\bullet$ & & \\
\hline Tinodes pallidulus McLachlan & & & & & & & & $\bullet$ & & & & \\
\hline Family Hydropsychidae & & & & & & & & & & & & \\
\hline Diplectrona cf. atra McLachlan & & & & $\bullet$ & $\bullet$ & $\bullet$ & $\bullet$ & & & $\bullet$ & & \\
\hline Hydropsyche angustipennis Curtis & & & & & & & & $\bullet$ & & & & \\
\hline Hydropsyche fulvipes Curtis & & & & & & & $\bullet$ & & & & & \\
\hline Hydropsyche instabilis Curtis & & & & & & $\bullet$ & $\bullet$ & $\bullet$ & - & $\bullet$ & $\bullet$ & \\
\hline Family Goeridae & & & & & & & & & & & & \\
\hline Silo nigricornis Pictet & & & & - & & $\bullet$ & & & - & $\bullet$ & & \\
\hline Family Limnephilidae & & & & & & & $\bullet$ & & & & & \\
\hline Limnephilus lunatus Curtis & & & & & & & & & & & $\bullet$ & \\
\hline Halesus tesselatus Rambur & & & & & & & & & & - & & \\
\hline Micropterna wageneri Malicky & & & & & & & & & & $\bullet$ & $\bullet$ & \\
\hline Family Sericostomatidae & & & & & & & & & & & & \\
\hline Sericostoma flavicorne Schneider & & & & & & $\bullet$ & & $\bullet$ & & & & \\
\hline Family Odontoceridae & & & & & & & & & & & & \\
\hline Odontocerum albicorne Scopoli & & & & & & $\bullet$ & & $\bullet$ & & $\bullet$ & & \\
\hline Family Leptoceridae & & & & & & & & & & & & \\
\hline Adicella filicornis Pictet & & & & & $\bullet$ & $\bullet$ & & & & & & \\
\hline TOTAL NUMBER OF TAXA & - & - & - & 3 & 2 & 10 & 6 & 10 & 5 & 10 & 3 & - \\
\hline
\end{tabular}


Tab. 4. Collection details of DNA barcoded specimens from the Konavle region: Specimen ID marks in the collection "Pogledi Nova - Trichoptera DNA barcoding collection"; Locality; BOLD Sequence ID.

\begin{tabular}{|c|c|c|c|}
\hline Species & Specimen ID & Locality & $\begin{array}{c}\text { BOLD } \\
\text { Sequence ID }\end{array}$ \\
\hline Rhyacophila tristis & TRTRI_4 & spring in the village of Vodovađa & CROAA098-18 \\
\hline Rhyacophila tristis & TRTRI_5 & spring in the village of Vodovađa & CROTR011-19 \\
\hline Rhyacophila tristis & TRTRI_7 & spring in the village of Vodovađa & CROTR031-19 \\
\hline Agapetus cf. kampos & TAFUS_1 & spring of the River Ljuta & NIP011-17 \\
\hline Agapetus cf. kampos & TAFUS_2 & spring oh the River Ljuta & CROTR225-19 \\
\hline Agapetus cf. kampos & TAFUS_3 & spring of the River Ljuta & CROTR230-19 \\
\hline Agapetus cf. kampos & TAFUS_4 & spring of the River Ljuta & CROTR216-19 \\
\hline Agapetus cf. kampos (larva) & MK_1 & spring of the River Ljuta & CROTR347-21 \\
\hline Agapetus cf. kampos (larva) & MK_2 & spring of the River Ljuta & CROTR348-21 \\
\hline Tinodes andrasi & MK7 & spring of the River Ljuta & CROTR352-21 \\
\hline Tinodes andrasi & MK14 & spring of the River Ljuta & CROTR353-21 \\
\hline Tinodes braueri & MK70 & spring of the River Ljuta & CROTR354-21 \\
\hline Tinodes pallidulus & MK6 & spring of the River Ljuta & CROTR350-21 \\
\hline Hydroptila sparsa & THYP_6 & stream in the village of Pridvorje & CROTR196-19 \\
\hline Hydroptila vectis & THVEC_2 & stream in the village of Pridvorje & CROTR168-19 \\
\hline Oxyethira falcata & THYP_4 & stream in the village of Pridvorje & CROTR166-19 \\
\hline Oxyethira falcata & THYP_5 & stream in the village of Pridvorje & CROTR167-19 \\
\hline Oxyethira falcata & THYP_7 & stream in the village of Pridvorje & CROTR169-19 \\
\hline Diplectrona cf. atra & TDATR_1 & strema in the village of Palje Brdo & CROTR291-19 \\
\hline Diplectrona cf. atra & TDATR_2 & spring in the village of Vodovađa & CROTR292-19 \\
\hline Diplectrona cf. atra & TDATR_4 & spring of the River Ljuta & CROTR247-19 \\
\hline Diplectrona cf. atra & DIPL_1 & spring of the River Ljuta & CROTR293-19 \\
\hline Diplectrona cf. atra & DSPH2 & spring of the River Ljuta & CROTR294-19 \\
\hline Diplectrona cf. atra & DSPH4 & spring of the River Ljuta & CROTR295-19 \\
\hline Hydropsyche fulvipes & THINS_8 & stream in the village of Palje Brdo & CROTR163-19 \\
\hline Silo nigricornis & CROBK28 & the River Ljuta, upper part & CROTR363-21 \\
\hline Silo nigricornis & CROBK29 & spring in the village of Vodovađa & CROTR364-21 \\
\hline Silo nigricornis & CROBK30 & the River Ljuta, upper part & CROTR365-21 \\
\hline Silo nigricornis & CROBK31 & the River Ljuta, upper part & CROTR366-21 \\
\hline Silo nigricornis & CROBK32 & the River Ljuta, upper part & CROTR367-21 \\
\hline Silo nigricornis & CROBK33 & stream in village of Lovorno & CROTR368-21 \\
\hline Silo nigricornis & CROBK34 & stream in village of Lovorno & CROTR369-21 \\
\hline Silo nigricornis & CROBK35 & the spring of Marija & CROTR370-21 \\
\hline Silo nigricornis & CROBK36 & spring of the River Ljuta & CROTR371-21 \\
\hline Micropterna wageneri & TMWAG_1 & stream in the village of Palje Brdo & NIPM001-17 \\
\hline Micropterna wageneri & TPWAG_1 & stream in the village of Palje Brdo & NIPM002-17 \\
\hline Sericostoma flavicorne & CROBK38 & spring in the village of Vodovađa & CROTR372-21 \\
\hline Odontocerum albicorne & CROBK39 & the River Ljuta, upper part & CROTR373-21 \\
\hline Odontocerum albicorne & CROBK40 & spring in the village of Vodovađa & CROTR374-21 \\
\hline Adicella filicornis & MK4 & spring of the River Ljuta & CROTR349-21 \\
\hline Adicella filicornis & MK6 & spring of the River Ljuta & CROTR351-21 \\
\hline
\end{tabular}


of Trichoptera species will also increase. The Konavle field is located in the southernmost part of Croatia, which is close to the border to Bosnia and Herzegovina, and Montenegro. Since these countries have a very specific caddisfly fauna (e.g. KRUŠnIK, 1987; Marinković-Gospodnetić, 1976, 1978, 1979, 1988; Stanić-Koštroman et al., 2015) it is possible that more new species will be reported.

The relatively small number of the species recorded does not diminish the faunistic value of the Konavle region, on the contrary. If compared to other Croatian regions (e.g. Cerjanec et al., 2020; Kučinić et al., 2011, 2017b; Previšić et al., 2013; VučKović et al., 2021), the Trichoptera fauna of Konavle is a very interesting segment of Croatian caddisfly fauna, e.g. locus typicus for Tinodes andrasi Oláh, new species for fauna of Croatia, Agapetus cf. kampos Oláh, for its Mediterranean part, e.g. Hydroptila martini Marshall or record of Diplectrona cf. atra McLachlan. These faunistic and taxonomic results show that the area of Konavle, as an isolated valley in the south of Croatia (BERTić et al., 2001; http:/ / www.enciklopedija.hr), went through geological processes that led to its isolation and resulted in some segments in the specific structure of the Trichoptera fauna in this part of Croatia.

In this research altogether 11 families of Trichoptera were recorded, with the highest number of four species recorded per family from the families Hydroptilidae, and Hydropsychidae (Tabs 1-3) and only one species per family for seven families (Tabs 1-3). New species can most probably be expected as well as from the family Limnephilidae, which is the most numerous European family, and from the families Rhyacophilidae, Polycentropodidae and Leptoceridae. Nonetheless, records from other families are also possible. Until now, for example no species from the family Philopotamidae or Lepidostomatidae have been recorded, but future findings cannot be ruled out. According to the data in this study and other caddisflies studies in Croatia (e.g. Cerjanec et al., 2020; Kučinić et al., 2011, 2017b; VučKović et al., 2021), including the hydrological features of Konavle and other areas (the rivers Cetina, Dobra, Krka and their tributaries, the Plitvice Lakes National Park), we can conclude that we have registered about $70 \%$ of the potential fauna of caddisflies of Konavle region, which had about 30 potential species.

The highest number of species was recorded on the locality spring of the River Ljuta (Tab. 2). According to its hydrological features and different types of aquatic microhabitats, this is no surprise (Fig. 2 A). Interesting fauna was also recorded on the small stream in the village of Pridvorje. At this locality alone, four species from the family Hydroptilidae were recorded (Tab. 2). In future studies, smaller streams and watercourses will be given more attention and significance, for example the small stream in the village of Lovorno (Fig. 2 G-H).

The highest number of Trichoptera species was recorded during the warm months, which was also expected (Tab. 3) and is consistent with similar surveys in other parts of Croatia (CERJANEc et al., 2020; Kučinić et al., 2017b; VučKović et al., 2021).

Because of the need to supplement data on seasonal dynamics, a part of the future fieldwork will be carried out in winter months (November and December), and in spring (March and May). Throughout the present research, the most interesting months were October, with ten recorded species and November, with three recorded species. This is consistent with the Mediterranean features of the climate in Konavle region, and the Trichoptera biodiversity of this period.

A faunistic preview of some interesting Trichoptera species (Agapetus cf. kampos Oláh, Hydroptila martini Marshall, Oxyethira falcata Morton, Tinodes andrasi Oláh, 
Diplectrona cf. atra McLachlan and Micropterna wageneri Malicky) that have been recorded during this research will be given.

The species Agapetus cf. kampos Oláh (Fig. 3 A-C) belongs to one of the most common Trichoptera species in Konavle region. A great number of collected female and male imagines, and larvae, all originate from the localities spring of the River Ljuta and upper stream of the Ljuta. The examination of genitalia of a large number of males showed specific morphological varieties of Agapetus cf. kampos Oláh from Konavle (OláH \& Kovács, 2013). The River Ljuta is the second locality of this species after its type locality at Basa spring (Mt Rumija) in Montenegro (OláH \& Kovács, 2013). Since Agapetus cf. kampos was described based on two male specimens, in future studies more specimens of both sexes have to be collected from Montenegro, to make a detailed morphological analysis, to perform DNA barcoding, and define the exact taxonomic status of its population in Konavle region. Future studies should also aim at describing undescribed female specimens and undescribed larvae from the populations in Konavle region.

According to Fauna Europea (https:/ / fauna-eu.org), Hydroptila martini Marshall, is distributed in Great Britain, Central Europe, Italy and Spain (https:/ / fauna-eu.org; BARNARD \& Ross, 2012). The finding from Konavle region is the third finding of this species in Croatia, the first finding being from Lika and the second finding being from the Panonian-peripanonian part of Croatia (KuČinić et al., 2020b). It also represents the first finding of this species from Mediterranean parts and southeastern Europe. Morphological determination was confirmed by DNA barcoding (Tab. 4). This species belongs to the smallest caddisfly species in Croatia (microtrichoptera), with an anterior wingspan from 2.5 to $3.5 \mathrm{~mm}$ (MALICKY, 2004). DNA barcoding is a very useful method for identifying taxonomically difficult species (BĄCZKIEwICZ et al., 2017), in present study that was the case for Hydroptila martini Marshall, but also other species from family Hydroptilidae (Tab. 4).

The species Oxyethira falcata Morton is not rare as it is distributed throughout most parts of Europe (Fauna Europea, https://fauna-eu.org; O'Connor, 2015; Hickin, 1967). It was previously not reported from Norway, Sweden, Poland and Baltic countries (Fauna Europea; O'Connor, 2015). Nonetheless, the finding from Konavle region is the first one from Croatia. Morphological determination was confirmed by DNA barcoding (Tab. 4). Larvae have the typical morphology of the family Hydroptilidae. The first four larval stages do not build cases, only the fifth stages do, and is very different from the earlier instars. They are herbivores that eat aquatic algae. Larvae can be found in streams, rivers and lakes and adults were also found at stagnant pools in a marsh (https://trichopteraireland.wordpress.com; O'ConNOR, 2015). The size of the imago is $3.5 \mathrm{~mm}$ (MaLicky, 2004) and it flies from May until October (O'Connor, 2015).

Tinodes andrasi Oláh (Fig. 4) is an endemic species of the Dinarides. It was described in the year 2010 (ОцÁH, 2010) with its locus typicus being the upper stream of the River Ljuta. Tinodes andrasi Oláh has only been reported from Konavle polje (OLÁH, 2010) and one locality (Črnojevica) in Montenegro (MaLickY, 2018). Our DNA barcoding results show that the population from Konavle region has a difference of $1.5 \%$ from the population of Tinodes rostocki McLachlan in Europe. Based on the morphological features, the population from Konavle could have a subspecies status, which will be covered in another study.

Diplectrona cf. atra McLachlan (Fig. 5 A) was reported for the second time in Croatia. The first record originates from Mt Papuk in Pannonian/peripannonian Croatia 
(Previšić et al., 2013). Besides Agapetus cf. kampos Oláh and Silo nigricornis Pictet it is one of the most numerous species in the River Ljuta and Konavle region. The results of DNA barcoding show certain specifics of the populations from Konavle, which will be analyzed in more detail in the results of the study of Croatian Trichoptera DNA barcode library (under preparation). Diplectrona cf. atra McLachlan has a disjunct areal with a partial distribution in West Europe (France, Spain), and a partial distribution in southeastern Europe (Bosna and Herzegovina, Greece, Bulgaria) (Fig. 5 B, Fauna Europea; Kumanski, 1985; Malicky, 2005).

The species Micropterna wageneri Malicky was described based on specimens that were collected in Italy (MALICKY, 1971). In Croatia, M. wageneri Malicky was reported not only from the Konavle region but on Mt. Biokovo as well (Kučinić et al., 2017a). It belongs to the group of Mediterranean species and was also reported from Montenegro and Serbia (KuČInIĆ et al., 2017a, Fauna Europea). According to GRAF et al. (2008b), it is a montane species, which was confirmed by our findings from Biokovo (KučINIć et al., 2017a), but not from Konavle region where it was reported only from localities at lower altitudes of $150 \mathrm{~m}$ (brook in the village of Palje Brdo). Like other species from the genus, Micropterna Stein, this species can be found in caves as part of the troglophile fauna (MoretTI, 1988).

Due to the faunistic characteristics of the Trichoptera fauna from the Konavle region future activities should be aimed at establishing a special attitude towards this area, as well as the protection of this hotspot of Croatian Trichoptera biodiversity.

\section{CONCLUSION}

The area of Konavle, the southernmost area of Croatia, represents one of the most interesting regions for Trichoptera fauna. Due to specific hydrological features and the sensitivity of such biotopes (springs, brooks, channels), it is necessary to install high standards for their protection, without major anthropogenic influence and with agricultural activities that should be aimed at the highest level of ecological production. In relation to the Croatian fauna, the area of Konavle represents a hotspot (not according to number of species, but because of the finding of very interesting species) for caddisflies with an interesting and special Trichoptera fauna. Legal protection only makes sense if it is aimed at the protection of habitats. Education of the local community represents one of the most important factors for the active protection of the biodiversity of a region such as Konavle. Nonetheless, the hydrological regime that was detected during the last 20 years must be maintained with the lowest possible negative effect from humans.

The DNA barcoding method proved to be very important and in fact essential in confirming the results of morphological determination (e.g. GERACI et al., 2011; HeBERT et al., 2004; KumARA et al., 2019; YANG et al., 2015; ZHou et al., 2016).

\section{ACKNOWLEDGEMENTS}

This research was supported by fundings from the Croatian Science Foundation by the scientific project "DNA barcoding of Croatian faunal biodiversity" (IP-201606-9988) and Dora Hlebec through ESF (DOK-2018-09-1417). 


\section{REFERENCES}

Barnard, P. \& Ross, E., 2012: The Adul Trichoptera (Caddisflies) of Britain and Ireland, Vol.1, Part 17. Royal Entomological Sociaty, pp. 198.

Bączkiewicz, A., Szczecińska, M., Sawicki, J., Stebel, A. \& Buczkowska, K., 2017: DNA barcoding, ecology and geography of the cryptic species of Aneura pinguis and their relationships with Aneura maxima and Aneura mirabilis (Metzgeriales, Marchantiophyta). Plos One. https://doi.org/10.1371/ journal.pone.0188837

Bertić, I., Lampek Pavčnik, I. \& Radovinović, R., 2001: Satelitski atlas Hrvatske. Naklada Ljevak i Gisdata, Zagreb, pp. 360.

Cerjanec, D., Kučinić, M., Vilenica, M., Ćukušić, A., Ćuk, R., Ibrahimi, H., Vučković, I., Žalac, S. \& Ruk, D., 2020: Ecological and faunistic features of caddisflies (Insecta: Trichoptera) in different types of habitats in the Dinaric karst area (Central Croatia). Ecologica Montenegrina 36, 6-39. dx. doi.org/10.37828/em.2020.36.2

Fauna Europea, https:/ / fauna-eu.org, (Accessed 4 July 2021).

Folmer, O., Black, M., Hoen, W., Lutz, R. \& Vrijenhoek, R., 1994: DNA primers for amplification of mitochondrial cytochrome c oxidase subunit I from diverse metazoan invertebrates. Molecular Marine Biology and Biotechnology 3, 294-299.

Geraci, C. J., Al-Saffar, M. A., \& Zhou, X., 2011: DNA barcoding facilitates description of unknown faunas: a case study on Trichoptera in the headwaters of the Tigris River, Iraq. Journal of the North American Benthological Society 30 (1), 163-173.

Germar, F. E., 1817: Reise nach Dalmatien und in das Gebiet von Ragusa. Leipzig.

Graf, W., Kučinić M., Previšić A. Vučković I.\& Waringer J., 2008a: The Larva, ecology and distribution of Tinodes braueri McLachlan, 1878 (Trichoptera: Psychomyiidae). Aquatic insects 30, $295-299$.

Graf, W., Murphy J., Dahl J., Zamora-Muñoz C.\& López-Rodríguez M. J., 2008b: Distribution and Ecological Preferences of European Freshwater Species. Volume 1: Trichoptera. A. SchmidTKloiber \& D. Hering (eds). Pensoft, p. 399, Sofia-Moscow.

Hall, T. A., 1999: BioEdit: A user-friendly biological sequence alignment editor and analysis program for Windows 95/98/NT. Nucleic Acids Symposium Series 41, 95-98.

Hebert, P. D. N,, Stoeckle, M. Y., Zemlak, T. S. \& Francis, C. M., 2004: Identification of Birds through DNA Barcodes. Plos Biology 2 (10), e312.

Hebert, P. D. N., Stoeckle, M. Y., Zemlak, T. S \& Francis, C. M., 2004: Identification of birds through DNA Barcodes. Plos Biology 2 (10), e312.

Hickin, N. E, 1967: Cadiss Larvae, Larvae of the Britsh Trichoptera. Hutchinson of London pp. 476.

https:/ / doi.org/10.1371/journal.pbio.0020312

http:/ / www.enciklopedija.hr/Natuknica.aspx?ID=32705 Konavle. Hrvatska enciklopedija, mrežno izdanje. Leksikografski zavod Miroslav Krleža, 2021 (acessesd 28 August 2021).

https:/ / trichopteraireland.wordpress.com (accessed 24 August 2021).

Karaouzas, I., Graf, W., Kuèinie, M., Vuèkovie, I. \& Waringer, I., 2015: The larva of Rhyacophila balcanica Radovanoviæ, 1953 (Trichoptera: Rhyacophilidae) with notes on ecology. Zootaxa 4057 (3), 444-450.

KRUŠNIK, C., 1987: Trichoptera (Insecta). Fauna Durmitora 2, 201-224.

Kučinić, M. \& Ilıć, D., 1993: Micropterna testacea Gmelin 1789 (Insecta, Trichoptera) nova vrsta u fauni tulara Republike Hrvatske. Rad HAZU 26, 125-131.

Kučinić, M., VučKović, I., Kutnjak, H., Š́nić Jelaska, L.\& Marguš, D., 2011: Diversity, distribution, ecology and biogeography of caddisflies (Insecta: Trichoptera) in the Krka River (National Park "Krka", Croatia). Zoosymposia 5, 255-268.

Kučinić, M., Ćukušić, A., Žalac, S., Podnar, M., Kambarovich, A. K., Akimbekova, N., MoldazhanovNA, Z. S. \& VuČKović, I., 2017a: First DNA barcoding and new records of Mediterranean caddisfly species Micropterna wageneri Mal. (Trichoptera, Limnephilidae) in Croatia with note on DNA barcoding and diversity of genus Micropterna in Croatia. Natura Croatica 26(1), 81-89.

Kučinić, M., Previšić A., Vajdić M., Tunjić M., Mihoci I., Žalac S., Sviben S., Vučković I., Trupković M. \& HabdiJA, I., 2017b: First systematic investigation of adults and second checklist of caddisflies of the Plitvice Lakes National Park with notes on research history, biodiversity, distribution and ecology. Natura Croatica 26 (2), 225-260. 
Kučinić, M., Ćukušić, A., Delić, A., Podnar, M., Gumhalter, D., Mičetić Stanković, V., Plantak, M., Èeple, G., Plavec, H. \& Marguš, D. 2019a: New species from the family Hydroptilidae in Croatian fauna collected in the Krka National Park with particular notice to biodiversity and DNA barcoding. Natura Croatica 28 (2), 441-454.

Kučinić, M., Ćukušić, A., Plavec, H., Landeka, M., Plantak, M., Vuković, M., Bukvić, V., Franjević, M., ŽAlac, S. \& Lukač, G., 2019b: Caddisfly fauna characteristics (Insecta, Trichoptera) of four Adriatic islands with a note on DNA barcoding. Natura Croatica 28 (2), 403-413.

Kučinić, M., Ćukušić, A., Ibrahimi, H., Plantak, M., Vuković, M., Bukvić, V. \& Vučković, I., 2020a: DNA barcoding and a new taxonomic status of the Triaenodes ochreellus lefkas Malicky, 1974 (Insecta, Trichoptera) with new distribution data. Ecologica Montenegrina 38, 172-185. http:// dx.doi.org/10.37828/em.2020.38.26

Kučinić, M., Ćukušić, A., Žalac, S., Delić, A., Cerjanec, D., Podnar, M., Ćuk, R., Vučković, I., Previšić, A., Vuković, M., Stanić Koštroman, S., Bukvić, V., Š́linović, A. \& Plantak, M., 2020b: Springs: DNA barcoding of caddisflies (Insecta: Trichoptera) in Croatia with notes on taxonomy and Conservation Biology. Natura Croatica 29 (1), 3-98.

Kumanski, K. P., 1985: Fauna Bulgarica 15 (Trichoptera, Annulipalpia). Bulgarskata Akademia na Naukite, Sofia, pp. 243.

Kumanski, K. P., 1988: Fauna Bulgarica, 19 (Trichoptera, Integripalpia). Bulgarskata Akademia na Naukite, Sofia, pp. 354.

Kumara, V., Kundua, S., Chakrabortya, R., Sanyalb, A., Rahab, A., Sanyala, O., Ranjana, R., Pakrashia, A., Tyagia, K. \& ChandraA, K., 2019: DNA barcoding of Geometridae moths (Insecta: Lepidoptera): a preliminary effort from Namdapha National Park, Eastern Himalaya. Mitochondrial DNA, Part B, 4 (1), 309-315. doi.org/10.1080/23802359.2018.1544037

MAlicky, H., 1971: Eine neue Micropterna (Trichoptera, Limnephilidae) aus Italien - mit einem überblick über die Gattungen Stenophylax, Micropterna und Mesophylax? Die Höhle (Wien) 22 (1), 15-19.

Malicky, H., 1979: Revision der Köcherfliegensammlung von Pater Gabriel Strobl im Naturhistorischen Museum Admont (Insecta, Trichoptera). Mitt. Abt. Zool. Landesmus. Joanneum 8, 11-42.

Malicky, H., 1980: Z. Arbeitsgem oest Ent. 32(1-2), 15.

Malicky, H., 2004: Atlas of European Trichoptera. Springer, Dordrecht, pp. 359.

Malicky, H., 2005: Die Köcherfliegen Griechenlands. Denisia 17, 1-240.

MaLicky, H., 2014: Lebensräume von Köcherfliegen (Trichoptera). Denisia 34, 1-280.

Malicky, H., 2018: Variabilität bei einigen europäischen und asiatischen Trichopteren (Psychomyiidae, Limnephilidae, Philopotamidae). Braueria 45, 35-42.

Marinković-Gospodnetić, M., 1976: The differentiation of Drusus species of the group bosnicus. In: Malicky, H. (Ed.), Proceedings of the First International Symposium on Trichoptera, Dr. W. Junk Publishers, The Hague, Netherland, pp. 77-85.

Marinković-Gospodnetić, M., 1978: The Caddis-flies (Trichoptera, Insecta) of Hercegovina (Yugoslavia). Godišnjak Biološkog Instituta Univerziteta u Sarajevu 31, 115-130

Marinković-Gospodnetić, M., 1979: Trichoptera (Insecta) velikih karstnih izvora u Dinaridima. Savez Društava Ekologa Jugoslavije. (eds. Čanak, M., Ilijanić, Lj., Gradojević, Z., Pejčınović, D., Popovska, O., Rauš, Đ., Stefanović, V., Žušančić, M., Žunjić, K.), 1837-1849.

Marinković-Gospodnetić, M., 1988: Dve nove vrste Glossosoma (Trichoptera, Insecta) u Jugoslaviji. Godišnjak Biološkog Instituta Univerziteta u Sarajevu 41, 41-47.

Moretti, G., 1988: Tricotteri del Museo Civico di Scienze Naturali "Enrico Caffi" di Bergamo. Riv. del Museo Civico di Scienze Naturali "Enrico Caffi" di Bergamo 13, 1-19.

Morse, J., 2021: Trichoptera World Checklist. http://entweb.clemson.edu/database/trichopt/index. htm (Accessed 14 August 2021.)

Nonvailler, G., 1989: Pioniri proučavanja insekata Dalmacije. Jugoslavensko Entomološko Društvo, Zagreb, pp. 390.

O'Connor, J. P., 2015: A Catalogue and Atlas of the Caddisflies (Trichoptera) of Ireland. Occasional Publication of the Irish Biogeographical Society, No. 11. Irish Biogeographical Society in association with the National Museum of Ireland, Dublin, pp. 646.

OláH, J., 2010: New species and new records of Palearctic Trichoptera in the material of the Hungarian Natural History Museum. Annales Historico Naturales Musei Nationalis Hungarici 102, 65-117. 
OlÁH, J. \& KovÁcs, T., 2013: New species and records of Balkan Trichoptera II. Folia Historico Naturalia Musei Matraensis 37, 109-121.

Previšıć, A., Ivković, M., Miliša, M. \& Kerovec, M., 2013: Fauna tulara (Insecta: Tichoptera) Parka prirode Papuk, Hrvatska. Natura Croatica 22 (1), 1-13.

Previšić A., Graf W., Vitecek S., Kučinić M., Bálint M., Keresztes L., Pauls S. U., \& Waringer, J., 2014: Cryptic diversity of caddisflies in the Balkans: the curious case of Ecclisopteryx species (Trichoptera: Limnephilidae). Arthropod Systematics \& Phylogeny 72(3), 309-329.

Ratnasingham, S. \& Hebert, P. D. N., 2007: BOLD: The Barcode of Life Data System (http:/ /www. barcodinglife.org). Molecular Ecology Notes 7(3), 355-364.

Ridl, A., Previšić, A., Ivković, M. \& Mihaljević, Z., 2017: Emergencija tulara (Trichoptera, Insecta) sedrenih barijera u NP "Krka". Zbornik radova sa znanstveno-stručnog skupa vizija i izazovi upravljanja zaštićenim područjima prirode u Republici Hrvatskoj: aktivna zaštita i održivo upravljanje u Nacionalnom parku Krka / MARguš, D. (ur.). Šibenik: Javna ustanova "Nacionalni park Krka", 183-194.

Stanić-Koštroman, S., Previšić, A., Planinić, A., Kučinić, M., Škobić, D., Dedić, A. \& Durbešić, P., 2015: Environmental determinants of contrasting caddisfly (Insecta, Trichoptera) biodiversity in the Neretva and Bosna River basins (Bosnia and Herzegovina) under temperate and Mediterranean climates. International Review of Hydrobiology 100 (2), 79-95.

ŠAlinović, A., 2019: Faunističke značajke tulara (Insecta, Trichoptera) Konavala. Diplomski rad, Priorodoslovno-matematički fakultete, Sveučilište u Zagrebu, pp. 44.

Vučković, I., Previšić, A., Graf, W. \& Kučinić, M., 2011: Description of the female and distribution of Annitella apfelbecki Klapálek, 1899 (Insecta: Trichoptera). Aquatic Insects 33, 381-389.

Vučković, I., Kučinić, M., Ćukušić, A., Vuković, M., Ćuk, R., Stanić-Koštroman, S., Cerjanec, D. \& Plantak, M., 2021: Biodiversity, DNA barcoding data and ecological traits of caddisflies (Insecta, Trichoptera) in the catchment area of the Mediterranean karst River Cetina (Croatia). Ecologica Montenegrina 44, 19-25. http:/ /dx.doi.org/10.37828/em.2021.44.3

Waringer, J., Graf W., Kučinić M., Previšić, A. \& Vučković, I., 2009: The Larva and life cycle of Annitella apfelbecki Klapalek, 1899, including a re-description of Melampophylax nepos McLachlan, 1880 (Trichoptera: Limnephilidae). Aquatic insects 31, 71-80.

YANG, M., ZhaI, Q., YANG, Z. \& Zhang, Y., 2015: DNA barcoding Satyrine butterflies (Lepidoptera: Nymphalidae) in China. Mithochondrial DNA (Early online) 1-6. DOI: 10.3109/19401736. 2015.1038788

Zhou, X., Frandsen, P. B., Holzenthal, R. W, Beet, C. R., Bennett, K. R., Blahnik, R. J., Bonada, N., Cartwright, D., Chuluunbat, S., Cocks, G. V., Collins, G. E., De Waard, J., Dean, J., Flint Jr., O. S., Hausmann, A., Hendrich, L., Hess, M., Hogg, I. D., Kondratieff, B. C., Malicky, H., Milton, M. A., Moriniére, J., Morse, J. C., Mwangi, N. F., Pauls, S. U., Gonzalez, M. R., Rinne, A., Robinson, J. L., Salokannel, J., Shackleton, M., Smith, B., Stamatakis, A., St Clair, R., Thomas, J. A., Zamora-Munõz, C., Ziesmann, T. \& KJer, K. M., 2016: The Trichoptera barcode initiative: a strategy for generating a species-level Tree of Life. Philosophiical Transactions B 371, 20160025. doi: $10.1098 /$ rstb.2016.0025 